\title{
First record of Anthomyiidae (Diptera) from New Caledonia with key to Australasian and Oceanian species of Anthomyia Meigen
}

\author{
Márcia S. Couri ${ }^{1,2} \&$ Francisco de Assis Rodrigues-Júnior ${ }^{1,3}$
}

\author{
'Departamento de Entomologia, Museu Nacional, 20940-040 Rio de Janeiro-RJ, Brazil. courimarcia@gmail.com; rodriguesjuniorfa@gmail.com \\ ${ }^{2} \mathrm{CNPq}$ fellow \\ ${ }^{3} \mathrm{CNPq} / \mathrm{PROTAX}$ fellow
}

\begin{abstract}
First record of Anthomyiidae (Diptera) from New Caledonia with key to Australasian and Oceanian species of Anthomyia Meigen. The Anthomyiidae (Diptera) are known from about 1,100 species mostly occurring in temperate to arctic areas in the northern hemisphere. Few species have been reported from the Australasian and Oceanian Regions. New Caledonia, located in Melanesia, in the southwest Pacific Ocean, is well known for its high diversity, endemism and large number of unknown species. Specimens of Anthomyia Meigen from New Caledonia were found at the Muséum national d'Histoire naturelle (Paris) collection. The species was identified as A. medialis Colless, and represents the first record of Anthomyiidae from the island. A key to the Anthomyia species occurring in these regions is presented, as well as illustrations of the male terminalia of $A$. medialis.
\end{abstract}

KEYWORDS. Anthomyiidae; Anthomyia medialis; key to species; new record; taxonomy.

RESUMO. Primeiro registro de Anthomyiidae (Diptera) da Nova Caledônia com chave para espécies de Anthomyia Meigen da Australásia e Oceania. São conhecidas cerca de 1.100 espécies de Anthomyiidae (Diptera) ocorrendo principalmente em áreas temperadas e árticas no hemisfério norte. Poucas espécies têm sido relatadas nas regiões da Australásia e Oceania. Nova Caledônia, localizada na Melanésia, no sudoeste do Oceano Pacífico, é bem conhecida por sua alta diversidade, endemismo e grande número de espécies desconhecidas. Espécimes de Anthomyia Meigen da Nova Caledônia foram encontrados na coleção do "Muséum national d'Histoire naturelle" (Paris). A espécie foi identificada como A. medialis Colless, sendo este o primeiro registro de Anthomyiidae da ilha. Chave de identificação para as espécies de Anthomyia ocorrentes nessas regiões é apresentada, bem como ilustrações da terminália masculina de $A$. medialis.

PALAVRAS-CHAVES. Anthomyiidae; Anthomyia medialis; chave para espécies; novo registro. taxonomia.

The Anthomyiidae (Diptera) has about 1,100 species described worldwide (Evenhuis 2007), mostly occurring in areas with temperate and arctic climates, predominating in boreal habitats. Adults are found in a wide range of habitats, including woodlands, heaths, grasslands, deserts, and abundantly in arctic tundra, but a few species are synanthropic. Some are found on flowers where they feed on nectar and pollen while others, particularly some of the genus Delia Robineau-Desvoidy, are important agricultural pests (Huckett 1987; Evenhuis 2007).

The family comprises small to moderately large flies, 2.0$12.0 \mathrm{~mm}$ long, usually yellow, brown, grey, but never metallic colored. Eyes are normally holoptic in male and dichoptic in female. Proepisternum, anepimeron, meron, and prosternum are usually bare but occasionally haired. Meron always without strong setae and katepisternum with an anterior and a posterior setae on upper margin. Legs of male are usually with longer and stronger setae than in female (Huckett, 1987).

Anthomyiidae are placed in the Muscoidea superfamily together with Muscidae, Fanniidae and Scathophagidae (McAlpine 1989), from which they can be easily distinguished by the presence of fine setae on ventral surface of the scutellum (except in a few species) and by the long vein $\mathrm{A} 1+\mathrm{CuA} 2$ reaching wing margin.
According to Evenhuis (2007), 15 species has been recorded from the Australasian and Oceanian Regions, distributed in the following five genera: Anthomyia Meigen, Botanophila Lioy, Delia Robineau-Desvoidy, Fucellia Robineau-Desvoidy and Paregle Schnabl. From them, Anthomyia is the most speciose genus, represented by six species: A. fumipennis Stein, 1919, A. medialis Colless, 1982, A. pluvialis Linnaeus 1758, A. punctipennis Wiedemann, 1830, A. silvestris Colless 1982 and A. vicarians Schiner, 1868. Concerning A. fumipennis, Ackland (1987) called attention to the very different male and female terminalia of this species when compared with the other Anthomyia.

New Caledonia Islands, located at Melanesia, in southwest Pacific Ocean, are well known for their high diversity and endemism representing a complex mosaic of ecosystems with some singular species according to Heads (2008). The Memoires du Muséum national d'Histoire naturelle (Paris) has been publishing many papers on new caledonian fauna, with descriptions of new species, revisions among other contributions, in the volumes of "Zoologia Neocaledonica". Many dipteran families have been treated. Couri et al. (2010) recently revised the Muscidae from New Caledonia.

The present paper records the Anthomyiidae family for the first time from New Caledonia, and provides keys to identification of the Australasian and Oceanian species of Anthomyia. 


\section{MATERIAL AND METHODS}

This study was based on adult specimens deposited in the collection of Muséum national d'Histoire naturelle (MNHN, Paris, France), collected by Rageau in New Caledonia in 1958 and with a genus identification label of Dr. Satoshi Shinonaga (National Science Museum, Tokyo) as Anthomyia.

The key to species provided here was based on Colless (1982) and Ackland (1987) and includes the species of Anthomyia recorded from the Australasian and Oceanian Regions. The morphological terminology followed McAlpine (1981).

The specimens are deposited at the Muséum national d'Histoire naturelle (MNHN) and Museu Nacional, Universidade Federal do Rio de Janeiro (MNRJ) as stated under Material examined.

\section{RESULTS}

The material examined was identified as Anthomyia medialis Colless (1982), herein recorded for the first time from New Caledonia, being the first Anthomyiidae so far recorded from this region. Formerly, this species was only recorded from Australia (Queensland and New South Wales).

Colless (1982) presented the description of the species with an illustration of the male pregonite. The male terminalia was herein dissected to confirm the identification and sternite 5, cercal plate and phallic complex are described and illustrated as Colless (1982) described and illustrated only the gonites.

Male terminalia. Sternite 5 quadrangular, inner margins of its processes with numerous setae (Fig. 1); cercal plate heartshaped; surstylus long, each with a long and strong seta on inner margin close to the apex (Fig. 2); phallic complex as in Fig. 3; postgonite (Fig. 4) with median posterior prominence with a flattened setula, tip with 2-3 minute setulae.

Material examined: NEW CALEDONIA. Nouméa (Anse Vata), vii.1958, J. Rageau. Anthomyia S. Shinonaga det. 198 [data incomplete]. 1 male (MNRJ), 3 females (1 MNRJ, 2 MNHN), 1 specimen only with the thorax (MNHN).

\section{Key to Anthomyia species recorded from Australasian and} Oceanian Regions (partially based on Colless1982 and Ackland 1987)

1. Mesonotum grey or greyish brown, with 3 longitudinal brown stripes of equal width, the central one extending to the scutellum; proepisternum bare on centre; wing with dark spots on apex of vein R1 and ends of crossveins ....

A. punctipennis Wiedemann

1'. Mesonotum pattern different from above, without 3 longitudinal brown stripes; proepisternum haired on centre; wing not colored as above

.. 2

2. Mesonotum with postsutural brown markings divided into three separate spots, with a grey polinose area between them. Additional characters: sternite 5 with inner basal margin of lobes not dilated; postgonite with widely expanded seta (respectively, Figs. 25 and 23 of Ackland 1987)

A. pluvialis Linnaeus

2'. Mesonotum with postsutural brown markings forming an entire crossband 3

3. Mesonotum mainly dark; mesepisternum extensively dark; wing strongly brown infuscated [additional characters (Ackland 1987): sternite 5 without ventrally directed membranous lobe, cercal plate without flattened apical setulae, surstylus simple and without stronger inner setae] .........

A. fumipennis Stein

3'. Mesonotum mainly pale; mesepisternum all, or nearly all, pale; wing clear

4. Scutellum all, or almost all, dark brown; mesonotum with the anterior black spots fused on anterior margin [additional character: male postgonite with the median posterior prominence with a flattened setula, tip with 2-3 minute setulae] A. medialis Colless

4'. Scutellum dark on at most the basal two-thirds; mesonotum usually with at most a vaguely fused pair of dark spots at anterior margin (except, rarely, in females) ................... 5

5. Scutellum with a dark brown basal transverse band and with 6-8 lateral setulae; hind tibia with 6-8 anterodorsal setae; male postgonite with a broad flattened seta leafshaped; pregonite with 2 setae, the apical one flattened.... A. vicarians Schiner

5'. Scutellum with a dark basal triangle, sometimes reaching the basal setae and with 4-6 lateral setulae; hind tibia with 4-5 anterodorsal setae; male postgonite with a slightly flattened setae; pregonite with a row of 4-5 setae, the most apical one flattened A. silvestris Colless

\section{DISCUSSION}

Anthomyia medialis was described from 6 specimens (2 males and 4 females). Colless (1982) called attention to the morphological similarity between $A$. medialis with A. vicarians and $A$. vicarians with $A$. silvestris, but all with distinct male terminalia.

Ackland (2001) placed these three species, together with the Afrotropical A. amoena (Macquart) and A. latilamina Ackland, the Oriental $A$. illocata Walker and A. plumiseta Stein (according to him probably a synonym of $A$. amoena) and perhaps the Japanese species A. pectoralis Suwa in the "Anthomyia amoena superspecies". The group was characterized by the male postgonite with a widely expanded setula on ventral margin, inner margins of processes of sternite 5 with only short setulae, posterior margins of sternite 4 straight and without dense setae and central process of synsternite $(6+7)$ minutely pilose.

Colless (1982) stated that the shape and extension of the brown mark on scutellum and the number of lateral setae are somewhat variable. The series of $A$. medialis also showed some intraspecific variation, but the male gonites confirmed the identification (the same as in Fig. 3 of Colless 1982). 

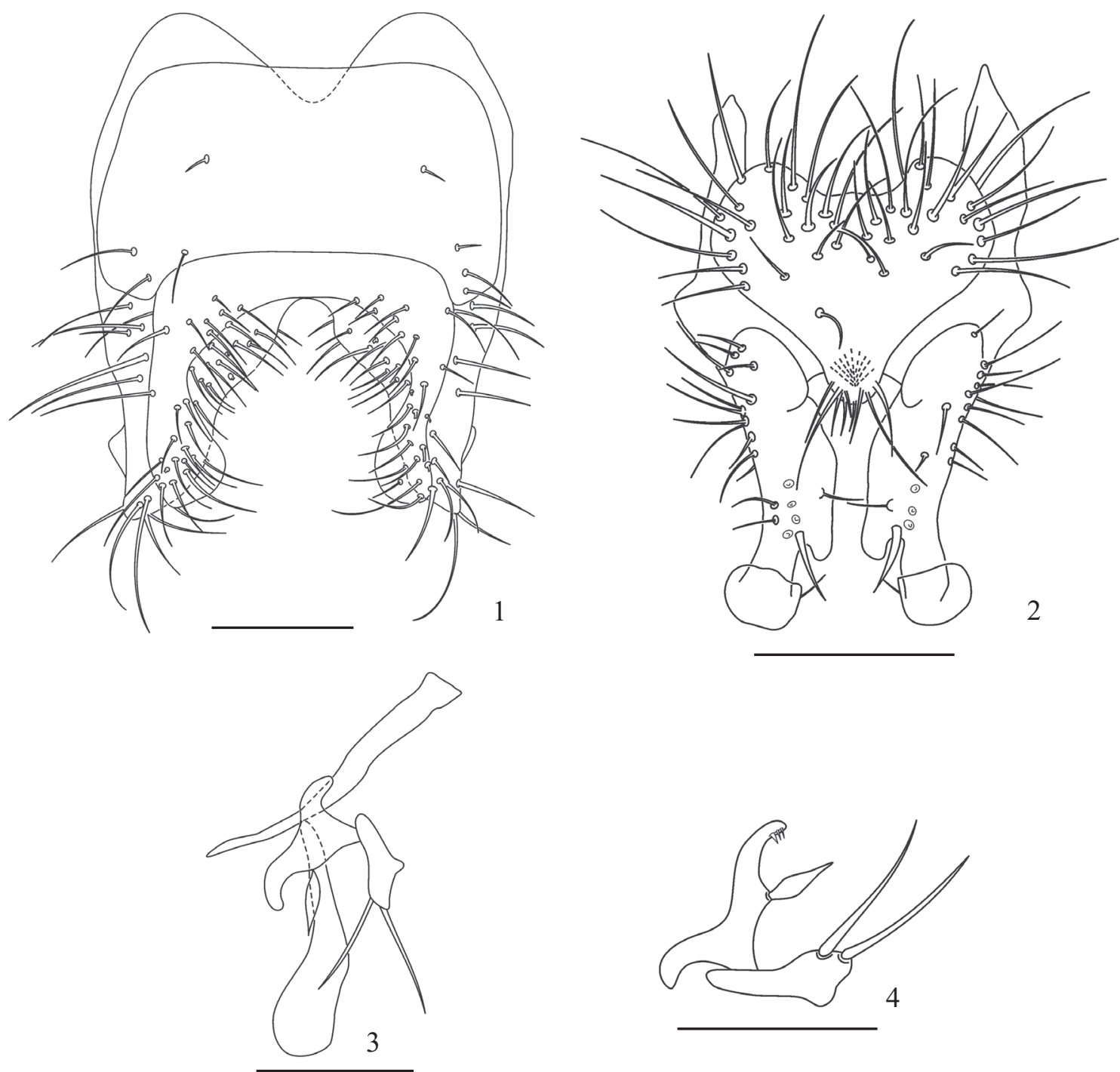

Figs. 1-4. Anthomyia medialis Colless, male: 1, sternite 5; 2, cercal plate, dorsal view; 3, phallic complex; 4, postgonite. Scale bars: $0.2 \mathrm{~mm}$.

Care must be taken when reading Colless (1982) paper as mistakenly the pages were wrongly numbered. The right sequence is: $81,82,83,88,89,86,87,84,85,90$ and 91 (maybe not in all copies).

\section{ACKNOWLEDGMENTS}

We thank Christophe Daugeron (MNHN) for providing the specimens and referees of the Revista Brasileira de Entomologia for the suggestions and improvement of the English.

\section{REFERENCES}

Ackland, D. M. 1987. The genus Anthomyia in the Oriental Region (Diptera: Anthomyiidae). Insecta Matsumurana 36: 39-60.

Ackland, D. M. 2001. Revision of afrotropical Anthomyia Meigen, 1803 (Diptera: Anthomyiidae), with descriptions of ten new species. African Invertebrates 42: 1-94.

Colless, D. H. 1982. Australian Anthomyiidae (Diptera). Australian Journal of Zoology 30: 81-91.
Couri, M. S.; A. C. Pont \& C. Daugeron. 2010. The Muscidae (Diptera) of New Caledonia. Zootaxa 2503: 1-61.

Evenhius, N. L. 2007. Family Anthomyiidae. Honolulu (HI): Bishop Museum; Available from: http://hbs.bishopmuseum.org/aocat/ anthomyiidae.html (accessed 20th 2010 September).

Heads, M. 2008. Panbiogeography of New Caledonia, south-west Pacific: basal angiosperms on basement terranes, ultramafic endemics inherited from volcanic islands arcs and old taxa endemic to young islands. Journal of Biogeography 35: 2153-2175.

Huckett, H. C. 1987. Anthomyiidae, p. 1099-1114. In: J. F. McAlpine (ed.). Manual of Nearctic Diptera. Ottawa, Agriculture Canada Research Branch, $1332 \mathrm{p}$.

McAlpine, J. F. 1981. Morphology and terminology: adults, p. 9-63. In: J. F. McAlpine, B. V. Peterson, G. E. Shewell, H. J. Teskey, J. R. Vockertoth \& D. M. Wood (eds.). Manual of Nearctic Diptera. Volume 1. Ottawa, Agriculture Canada Research Branch, 674 p.

McAlpine, J. F. 1989. Phylogeny and Classification of the Muscomorpha, p. 1397-1518. In: J. F. McAlpine \& D. M. Wood (eds.). Manual of Nearctic Diptera. Volume 3. Ottawa, Agriculture Canada Research Branch, 260 p.

Received 16/6/2011; accepted 10/5/2012

Editor: Silvio Shigueo Nihei 